\title{
The syndrome of inappropriate antidiuretic hormone secretion associated with acute myocardial infarction
}

\author{
G. HART \\ M.A., B.M., M.R.C.P. \\ R. GOKAL \\ M.B., M.R.C.P. \\ Nuffield Department of Clinical Medicine, The Radcliffe Infirmary, Oxford
}

\begin{abstract}
Summary
A 72-year-old man developed the syndrome of inappropriate antidiuretic hormone secretion after sustaining an acute myocardial infarction. Other documented causes of this syndrome were excluded, and this case is therefore reported as a new association.

\section{Introduction}

In 1957, Schwartz et al. described a condition of dilutional hyponatraemia with hypertonic urine and a normal plasma volume, in which the circulating antidiuretic hormone (ADH) levels were inappropriately raised. This has been observed in patients with a wide variety of disorders, in particular intrathoracic infection and neoplasia. In this report the authors describe a patient who developed the syndrome following acute myocardial infarction, an association not previously recorded.
\end{abstract}

\section{Case report}

A previously healthy 72-year-old man was admitted after an episode of central chest pain lasting $20 \mathrm{~min}$. On examination he was not shocked; the pulse was regular, $96 / \mathrm{min}$, blood pressure 14.63 / $11.3 \mathrm{kPa}$, and the jugular venous pressure was normal. A loud fourth heart sound was heard, and the chest was clear. Examination also revealed vitiligo and finger clubbing, both of which the patient claimed were lifelong.

An ECG showed sinus rhythm and changes of an inferior myocardial infarction. The enzymes rose appropriately, the plasma lactate dehydrogenase reaching a peak of $948 \mathrm{mi} . \mathrm{u} . / \mathrm{ml}$ on the third day. Chest X-ray revealed fibrotic scarring in the upper lobes suggestive of healed tuberculosis. He was treated with bed rest and low-dose subcutaneous heparin.

Two days after admission the patient was nauseated and vomited twice. He gradually became drowsy and withdrawn, and experienced a few short episodes of mild central chest pain. There were no

Correspondence: Dr G. Hart, Regional Cardiac Unit, Papworth Hospital, Papworth Everard, Cambridge CB3 8RE. signs of cardiac failure or dehydration and no postural hypotension. The ECG showed further ST segment elevation inferiorly and there was a short period of Mobitz type I block. By the third day the plasma sodium had fallen to $119 \mathrm{mmol} / 1$, urea $2 \cdot 8$ $\mathrm{mmol} / \mathrm{l}$. The plasma osmolality was $262 \mathrm{mosm} / \mathrm{kg}$, and the urine osmolality $642 \mathrm{mosm} / \mathrm{kg}$ (see Table 1). His fluid intake was restricted to one litre/day and his symptoms resolved by the sixth day.

Biochemical tests excluded Addison's disease, hypothyroidism and porphyria. Acid-fast bacilli and malignant cells could not be found in the sputum. A $1: 1000$ Mantoux test was negative. The urine arginine vasopressin on the third day was $410 \mathrm{pg} / \mathrm{min}$.

\section{Discussion}

In normal subjects, $\mathrm{ADH}$ is not detectable in the urine when the plasma osmolality falls below 283 mosm/kg (Miller and Moses, 1972). Thus, a high urinary ADH excretion with a plasma osmolality of $262 \mathrm{mosm} / \mathrm{kg}$ confirmed the diagnosis of inappropriate $\mathrm{ADH}$ secretion. A raised $\mathrm{ADH}$ secretion is, however, the opposite of what might be predicted in myocardial infarction. In animal experiments, an inverse relationship has been found between left atrial pressure and plasma ADH levels (Zehr, Johnson and Moore, 1969). The raised ventricular filling pressure often seen in myocardial infarction would therefore be expected to inhibit ADH release.

Apart from heparin, the only drug he received during the first two days was $5 \mathrm{mg}$ of morphine. It is unlikely, though, that this was responsible: it appears from studies in man, that in the absence of surgical shock, administration of morphine causes no change in serum electrolytes or osmolality, or in ADH output (Philbin et al., 1976).

Other documented causes of inappropriate ADH secretion were excluded, and it is difficult in this case to find a consequential link. Nevertheless, the authors conclude tentatively that the inappropriate $\mathrm{ADH}$ secretion was, in some way, caused by the myocardial infarct. 
TABLE 1. Biochemical changes after admission

\begin{tabular}{cccccc}
\hline $\begin{array}{c}\text { Day after } \\
\text { admission }\end{array}$ & $\begin{array}{c}\mathrm{Na} \\
(\mathrm{mmol} / \mathrm{l})\end{array}$ & $\begin{array}{c}\mathrm{K} \\
(\mathrm{mmol} / \mathrm{l})\end{array}$ & $\begin{array}{c}\text { Urea } \\
(\mathrm{mmol} / \mathrm{l})\end{array}$ & $\begin{array}{c}\text { Osmolality } \\
(\mathrm{mosm} / \mathbf{k g})\end{array}$ & $\begin{array}{c}\text { Urine } \\
\text { Osmolality } \\
(\mathbf{m o s m} / \mathbf{k g})\end{array}$ \\
\hline 0 & 133 & $4 \cdot 1$ & $3 \cdot 3$ & - & - \\
1 & 127 & $4 \cdot 9$ & $2 \cdot 2$ & - & - \\
2 & 122 & $4 \cdot 9$ & $1 \cdot 7$ & - & 507 \\
3 & 119 & $4 \cdot 3$ & $2 \cdot 8$ & 262 & 642 \\
4 & 124 & $4 \cdot 7$ & $5 \cdot 0$ & 267 & 869 \\
6 & 130 & $5 \cdot 2$ & $5 \cdot 3$ & 281 & - \\
39 & 131 & $4 \cdot 2$ & $4 \cdot 0$ & - & \\
\hline
\end{tabular}

\section{Acknowledgments}

The patient was under the care of Professor D. J. Weatherall, and we are grateful to him and to Professor D. G. Grahame-Smith for their advice in the preparation of this report.

\section{References}

Miller, M. \& Moses, A.M. (1972) Urinary antidiuretic hormone in polyuric disorders and in inappropriate ADH syndrome. Annals of Internal Medicine, 77, 715.

Philbin, D.M., Wilson, N.E., Sokoloski, J. \& Coggins, C.
(1976) Radioimmunoassay of antidiuretic hormone during morphine anaesthesia. Canadian Anaesthetists' Society Journal, 23, 290.

Schwartz, W.B., Bennett, W., Curelop, S. \& Bartter, F.C. (1957) A syndrome of renal sodium loss and hyponatremia probably resulting from inappropriate secretion of antidiuretic hormone. American Journal of Medicine, 23, 529.

ZeHR, J.E., Johnson, J.A. \& Moore, W.W. (1969) Left atrial pressure, plasma osmolality, and ADH levels in the unanesthetized ewe. American Journal of Physiology, 217, 1672.

\title{
Thrombophlebitis migrans in ulcerative colitis
}

\author{
Michael Camilleri \\ M.D.
}

FREDERICK F. FENECH
M.D., F.R.C.P., F.R.C.P.E.

St Luke Hospital, Guardamangia, Malta

\begin{abstract}
Summary
A case of thrombophlebitis migrans in ulcerative colitis in a Maltese housewife is reported. The association of thrombo-embolic disease and ulcerative colitis is reviewed.

\section{Introduction}

Although thrombo-embolic disease is a well recognized complication of ulcerative colitis, there has, however, so far been no recorded case in the literature of thrombophlebitis migrans in a patient with ulcerative colitis. The purpose of this paper is to record such a case in a Maltese housewife.

\section{Case history}

A 48-year-old married housewife was admitted to

Correspondence: Professor F. F. Fenech, Medical School, Royal University of Malta, G'Mangia, Malta, G.C.

hospital in November 1975 with a relapse of the ulcerative colitis, from which she had been suffering for the previous thirteen years. In the week before admission, she was passing a watery stool about once every hour, accompanied by fresh blood and mucus. She had tenesmus and abdominal pain. There was a fever of $38.8^{\circ} \mathrm{C}\left(102^{\circ} \mathrm{F}\right)$ and she was completely anorexic. She also had bronchial asthma for which she was taking sodium cromoglycate three times daily.

On examination, she was clinically not anaemic or jaundiced. There was no finger clubbing or eye involvement. The abdomen was soft and distended. There was tenderness in the right iliac fossa. There was, also, a brawny, warm, tender swelling on the medial aspect of the left arm.

The following investigations were carried out: ESR $35 \mathrm{~mm}$ in the first hour (Westergren); haemoglobin $12.4 \mathrm{~g} / \mathrm{dl}$; white cell count $8 \times 10^{\circ} / 1$ of which
\end{abstract}

